\title{
PENGARUH MODEL PEMBELAJARAN STUDENT FACILITATOR AND EXPLINING (SFAE) TERHADAP HASIL BELAJAR SISWA
}

\author{
Hardiyanti Windarti B. Hasan', Komang Sundara'2, Hafsah ${ }^{3}$ \\ ${ }^{1}$ Pendidikan Pancasila dan Kewarganegaraan, Universitas Muhammadiyah Mataram, hardiyanti.winarti3@gmail.com \\ ${ }^{2}$ Program Studi Pendidikan Pancasila dan Kewarganegaraan FKIP Universitas Muhammadiyah Mataram, komangsundara@gmail.com \\ ${ }^{3}$ Program Studi Pendidikan Pancasila dan Kewarganegaraan FKIP Universitas Muhammadiyah Mataram, dansa.manchi@yahoo.co.id
}

\begin{tabular}{l} 
INFO ARTIKEL \\
\hline Riwayat Artikel: \\
$\begin{array}{l}\text { Diterima: } \quad \text { 10-Januari- } \\
2017 \\
\text { Disetujui: } 12 \text { Maret-2017 }\end{array}$ \\
\hline
\end{tabular}

Kata Kunci:

Pengaruh

Pembelajaran SFAE

Hasil belajar

\section{A. LATAR BELAKANG}

Perkembangan ilmu pengetahuan dan teknologi serta perubahan sosial pada abad ini demikian pesat, sehingga menuntut adanya peningkatan mutu pendidikan yang diterapkan dengan berbagai metode, model, strategi dan pendekatan pembelajaran. Sekolah sebagai salah satu satuan pendidikan berkewajiban menyelenggarakan kegiatan pembelajaran bagi Pembina kepribadian siswa seutuhnya, oleh karena itu pemilihan model

\begin{abstract}
Abstrak: Pembelajaran Pendidikan Pancasila dan Kewarganegaraan di sekolah umumnya guru masih menerapkan model pembelajaran konvensional yaitu memberi materi melalui ceramah, karena itu hasil belajar peserta didik masih belum memenuhi standar ketuntasan dalam belajar, hal ini memerlukan tindak lanjut yang ril dari pihak guru untuk mencarikan jalan keluarnya. Penelitian ini bertujuan untuk mengetahui pengaruh penerapan model pembelajaran Student Facilitator And Explaining (SFAE) terhadap hasil belajar siswa. Jenis penelitian yang digunakan dalam penelitian ini adalah kuantitatif dengan pendekatan eksperimen, dimana semua anggota populasi yang dipilih. Dengan jumlah populasi adalah 55 siswa dari dua kelas yang dijadikan sampel. Pengumpulan data menggunakan tes, analisis data mengunakan analisis statistic dengan menguji homogenitas, validitas dan hipotesis. Berdasarkan hasil penelitian menunjukan bahwa diperoleh thitung 0,146 dan ttabel 2,02dengan taraf signifikan 0,05\% sehingga thitung > ttabel, maka hipotesis Ho diterima dan $\mathrm{Ha}$ ditolak, sehingga dapat disimpulkan bahwa siswa yang belajar dengan model pembelajaran Student Facilitator And Explining (SFAE) tidak memiliki pengaruh dari siswa yang belajar dengan model pembelajaran konvesional. Maka hipotesis Ho berbunyi "Tidak terdapat pengaruh model pembelajaran Student Facilitator And Explining (SFAE) terhadap hasil belajar siswa.
\end{abstract}

\begin{abstract}
Pancasila and Citizenship Education Learning in schools is generally teachers still apply conventional learning models, namely giving material through lectures, therefore learning outcomes of students still do not meet the standards of completeness in learning, this requires real follow-up from the teacher to find a solution. This study aims to determine the effect of applying the Student Facilitator And Explaining learning model (SFAE) on student learning outcomes. The type of research used in this study is quantitative with an experimental approach, where all members of the population are chosen. With the total population is 55 students from two classes that are sampled. Data collection uses tests, data analysis uses statistical analysis by testing homogeneity, validity and hypothesis. Based on the results of the study, it was found that tcount 0.146 and ttable 2.02 with a significant level of $0.05 \%$ so that tcount $>t$ table, then the hypothesis Ho was accepted and Ha was rejected, so it can be concluded that students studying with Student Facilitator And Explining (SFAE) learning models were have influence from students who study with conventional learning models. Then Ho's hypothesis reads "There is no effect of the Student Facilitator And Explosion learning model (SFAE) on student learning outcomes.
\end{abstract}

pembelajaran oleh guru bukan merupakan hal yang mudah, karena berbagai perbedaan kemampuan siswa.

Salah satu masalah pokok dalam pembelajaran pada pendidikan formal (sekolah) dewasa ini adalah masih rendahnya daya serap siswa, hal ini tampak rerata hasil belajar siswa yang senantiasa masih sangat memprihatinkan. Masalah ini banyak dijumpai dalam kegiatan proses belajar mengajar dikelas, oleh karena itu perlu menerapkan suatu strategi belajar dengan menggunakan model pembelajaran yang dapat 
membantu siswa untuk memahami materi ajar dan aplikasinya dalam kehidupan sehari-hari.

Kegiatan belajar mengajar adalah suatu kondisi yang dengan sengaja diciptakan, gurulah yang menciptakannya guna membelajarkan anak didik, guru yang mengajar dan anak didik yang belajar. Perpaduan kedua unsur manusiawi ini lahirlah interaksi edukatif dengan memanfaatkan bahan, disana semua komponen pengajaran diperankan secara optimal guna mencapai tujuan pengajaran yang telah ditetapkan sebelum pengajaran dilaksanakan[1]. Dalam interaksi itu anak didiklah yang lebih aktif bukan guru.Guru hanya berperan sebagai motivator dan fasilitator. Tugas guru berusaha menciptakan suasana belajar yang menggairahkan dan menyenangkan bagi semua anak didik.Suasana belajar yang tidak menggairahkan dan menyenangkan bagi anak didik biasanya lebih banyak mendatangkan kegiatan belajar mengajar yang kurang harmonis.

Model pembelajaran adalah suatu perencanaan atau suatu pola yang digunakan sebagai pedoman dalam merencanakan pembelajaran dikelas atau pembelajaran dalam tutorial dan untuk menentukan perangkatperangkat pembelajaran termasuk didalamnya bukubuku, film, komputer, kurikulum, dan lain-lain[2]. Menurut pendapat lain model pembelajaran adalah suatu pola mengajar yang menerangkan proses menyebutkan dan menghasilkan situasi lingkungan tertentu yang menyebabkan para siswa berinteraksi dengan cara terjadinya perubahan khusus pada tingkah laku mereka, dengan kata lain penciptaan suatu situasi lingkungan yang memungkinkan terjadinya proses belajar[3].

Salah satu model pembelajaran yang mendukung proses pembelajaran adalah model pembelajaran kooperatif. Didalam model pembelajaran kooperatif terdapat berbagai model pembelajaran salah satunya adalah tipe Student Facilitator And Explaining (SFAE). Dengan adanya model pembelajaran yang bervariasi ini dapat menarik siswa untuk lebih aktif dalam proses pembelajaran. Salah satunya diperlukan model yang mendukung situasi pembelajaran, agar pelajaran PPKn menjadi menarik, mudah dipahami dan menyenangkan sehingga akibat yang diharapkan dari keadaan tersebut adalah siswa dapat berkomunikasi dengan baik dan hasil belajar siswa juga meningkat. Model pembelajaran Student Facilitator and Explaining (SFAE) merupakan salah satu model pembelajaran kooperatif yang melibatkan keaktifan siswa dalam proses pembelajaran. Model pembelajaran kooperatif dengan menggunakan kelompok-kelompok kecil dengan jumlah anggota tiap kelompok 4-5 siswa secara heterogen.

Penggunaan model belajar yang baik akan berpengaruh pada hasil belajar. Hal itu juga berlaku pada mata pelajaran PPKn, sebagai mata pelajaran yang bersifat umum sehingga pembelajaran PPKn tidak hanya menuntut siswa untuk memahami tentang apa yang dipelajarai, tetapi juga harus mampu memberikan contoh-contoh sosial yang nyata dilingkungan masyarakat seputar materi yang disampaikan. Maka harus menggunakan model yang dapat meningkatkan keaktifan siswa yang akan berpengaruh terhadap peningkatan hasil belajar siswa, menggunakan model SFAE.

Hasil belajar pada dasarnya merupakan akibat dari suatu proses belajar. Ini berarti bahwa optimalnya hasil belajar siswa bergantung pula pada proses belajar siswa dan proses mengajar guru. Oleh sebab itu, perlu dilakukan penilaian terhadap proses belajar mengajar, tujuan penilaian proses belajar mengajar pada hakikatnya adalah untuk mengetahui kegiatan belajar mengajar terutama efisiensi, keefektifan, dan produktifitasnya dalam mencapai tujuan pengajaran. Hasil belajar yang dicapai oleh siswa untuk mengetahui sejauh mana siswa telah berhasil mengikuti pelajaran yang diberikan oleh guru. Dengan kata lain, tujuan usaha guru diukur dengan hasil belajar siswa melalui kegiatan belajar mengajar. Keberhasilan pengajaran tidak hanya dilihat dari hasil belajar yang dicapai oleh siswa, tetapi juga dari segi prosesnya.

Di MTs Nurul Qur'an proses pembelajaranya tidak dapat mencapai prestasi yang maksimal, rendanya prestasi belajar terlihat dari nilai mata pelajaran pendidikan kewarganegaraan yang tercatat pada hasil observasi ini bersifat konfersional yang didominasi oleh metode ceramah dan latihan menjawab soal yang ada dalam LKS. Sementara siswa hanya duduk, diam,mendengar,mencatat dan mengerjakan soal pada tempat duduknya saja.

Dapat didlihat dari nilai rata-rata siswa sehingga dalam proses pembelajaran siswa tidak aktif. Hal tersebut, sudah mencapai standar ketuntasan minimal yang ditetapkan yaitu 65 . Tetapi dilihat dari presentase klasikalnya $60 \%$ belum mencapai ketuntasan secara klasikal, dimana pembelajaran dikatakan tuntas secara klasikal jika presentase ketuntasan klasiklanya mencapai 80\%, sehingga perlu diterapkan model pembelajaran untuk menuntaskan hasil belajar siswa.

Berdasarkan indikasi tersebut terdapat masalah bahwa siswa-siswa memiliki kemauan yang rendah untuk belajar pendidikan kewarganegaraan disebabkan pembelajaran satu arah dimana lebih banyak kegiatan guru dari pada siswa, hanya siswa yang mempunyai kemampuan yang tinggi saja yang memperhatikan. Sehingga tidak semua siswa aktif dan paham dalam kegiatan pembelajaran.

Merujuk pada hasil obsevasi awal data presentase ketuntasan pada mata pelajaran PPKn kelas VIII MTs Nurul Qur'an Pagutan ditemukan permasalahan dalam proses pembelajaran antara lain: (1) rendahnya rangsangan siswa dalam menjawab pertanyaan yang dilontarkan guru, (2) jarangnya pertanyaan yang diajukan oleh siswa, dan (3) rendahnya hasil belajar 
siswa pada tahun pelajaran 2014 -2015. Berikut hasil nilai MID siswa pada tahun 2014-2015

Table 1

Data Nilai PPKn Mid Semester

\begin{tabular}{ccccc}
\hline No & $\begin{array}{c}\text { Rentang } \\
\text { nilai }\end{array}$ & $\begin{array}{c}\text { Juml } \\
\text { ah } \\
\text { sisw } \\
\mathbf{a}\end{array}$ & $\begin{array}{c}\text { presen } \\
\text { tase }\end{array}$ & $\begin{array}{c}\text { Keterang } \\
\text { an }\end{array}$ \\
\hline 1 & $80-100$ & 3 & $15 \%$ & Sangat Baik \\
2 & $60-75$ & 5 & $25 \%$ & Baik \\
3 & $40-55$ & 7 & $35 \%$ & $\begin{array}{c}\text { Kurang } \\
\text { baik }\end{array}$ \\
4 & $\begin{array}{c}35- \\
\text { kebawah }\end{array}$ & 5 & $25 \%$ & Tidak baik \\
\hline
\end{tabular}

Berdasarkan ketentuan KKM yang ditentukan untuk mata pelajaran PPKn yaitu 65 mendapat nilai baik 4 siswa atau $15 \%$ dari 20 siswa, mendapat nilai cukup baik 5 siswa atau 25\% dari 20 siswa,mendapat nilai kurang baik 7 atau 35\% dari 20 siswa dan mendapat nilai tidak baik 5 siswa atau $25 \%$ dari 20 siswa.

\section{B. METODE PENELITIAN}

1. Metode yang Digunakan

Penelitian ini adalah penelitian eksperimen, yaitu suatu cara untuk mencari hubungan sebab-akibat antara dua faktor yang sengaja ditimbulkan oleh peneliti dengan mengeliminasi atau mengurangi atau menyisikan faktor - faktor lain yang mengganggu. Eksperimen dapat diartikan sebagai metode penelitian yang bertujuan untuk mencari pengaruh perlakuan tertentu terhadap yang lain dalam kondisi yang terkendalikan[4].

Eksperimen adalah metode penelitian yang bertujuan untuk menjelaskan dan meramalkan yang akan terjadi pada suatu variabel manakala diberikan suatu perlakuan tertentu pada variabel lainnya.[5]

Maka kesimpulan dari metode eksperimen merupakan satu metode yang digunakan untuk mengetahui dan menjelaskan pengaruh perlakuan terhadap variabel yang satu dengan yang lain.

Salah satu cara penelitian eksperimen adalah menggunakankelompok kontrol sebagai garis dasar untuk dibandingkan dengan kelompok yang dikenali eksperimen. Kelas eksperimen diberi perlakuan dengan penerapan model pembelajaran Student Facilitator and Explaining, sedangkan untuk kelas kontrol diberi perlakuan berupa ceramah.

Dalam pelaksanaan Penelitian ini, peneliti menerapkan sebuah jenis penelitian yaitu Quasi Eksperimental dengan rancangan penelitian: Nonequivalent control group design.

2. Populasi dan Sampel

a. Populasi Penelitian
Populasi adalah keseluruhan yang menjadi target dalam menggeneralisasikan hasil penelitian (Wina Sanjaya, 2013: 228). Populasi adalah kelompok yang menjadi perhatian peneliti, kelompok yang berkaitan dengan untuk siapa generalisasi hasil penelitian berlaku. Penelitian ini menggunakan penelitian populasi, penelitian ini dilakukan karena peneliti ingin mengambil semua subjek yang terdapat dalam populasi.Objek pada populasi diteliti, hasilnya dianalisis, disimpulkan, dan kesimpulan itu berlaku untuk seluruh populasi.

Berdasarkan pendapat ahli di atas, maka yang menjadi populasi dalam penelitian ini adalah semua siswa kelas VIII di MTS Nurul Qur'an 2015/2016terdiri dari satu kelas.

Table 2

Populasi siswa MTS Nurul Qur'an Pagutan

\begin{tabular}{|c|c|c|c|c|}
\hline \multirow[b]{2}{*}{ No } & \multirow[b]{2}{*}{ Kelas VIII } & \multicolumn{2}{|c|}{ Siswa } & \multirow[t]{2}{*}{ jumlah } \\
\hline & & $\mathrm{P}$ & $\mathrm{L}$ & \\
\hline 1 & VIII A & 16 & 13 & 29 \\
\hline 2 & VIII B & 13 & 13 & 26 \\
\hline
\end{tabular}

b. Sampel Penelitian

Sampel adalah sebagian atau wakil populasi yang akan diteliti[6]. Sampel adalah bagian dari jumlah dan karakteristik yang dimiliki atau oleh populasi tersebut[7]

Dari pendapat diatas maka dapat disimpulkan bahwa sampel adalah bagian atau keseluruhan populasi yang digunakan sebagai bahan penelitian. Dalam penelitian ini menggunakan teknik sampling jenuh. Sampling jenuh adalah teknik penentuan sampel bila semua anggota populasi dipilih menjadi sampel. Peneliti menggunakan sampling jenuh karna populasi yang diteliti tidak terlalu besar[8].

3. Metode Pengumpulan Data

a. Tes

Tes adalah serentetan pertanyaan atau latihan serta alat lain yang digunakan untuk mengukur keterampilan, pengetahuan inteligensi, kemampuan atau bakat yang dimiliki oleh individu atau kelompok. (Suharsimi Arikunto,2002: 127).

Tes dalam penelitian ini adalah mengunakan tes obyektif yang diberikan kepada semua siswa kelas VIII MTs Nurul Qur'an Pagutan untuk mengetahui hasil belajar.

Adapun pengertian tes objektif adalah tes yang disusun sedemikian rupa dan telah disedikan alternatif jawabannya. Metode tes yang digunakan dalam penelitian ini adalah tes objektif bentuk pilihan ganda (multiple choise), karena mencakup banyak materi, penskorannya objektif, dan dapat dikoreksi oleh komputer maupun orang lain yang bukan bidangnya (Arikunto, 2007:109).

Dan jenis tes bentuk pilihan ganda yang akan dipilih oleh peneliti yaitu bentuk pilihan ganda Distracters, dimana setiap pertanyaan atau pertanyaan mempunyai beberapa pilihan ganda yang salah, tetapi disediakan satu pilihan jawaban yang benar. (Warni Djuwita, 2012 : 79) 


\section{b. Dokumentasi}

Dokumentasi adalah suatu metode yang mencari data mengenai hal-hal atau variabel yang berupa catatan, transkrip, buku, surat kabar, majalah, prasasti, notulen rapat, lengger, agenda, dan sebagainya[9]. Metode dokumentasi merupakan teknik pengumpulan data dengan menghimpun data menganalisis dokumen, baik dokumen tertulis, gambar maupun elektronik[10].

Kesimpulan dari metode dokumentasi berarti cara mengumpulkan data dengan mencatat data yang sudah ada. Metode dokumentasi dalam penelitian ini digunakan untuk mendapatkan data tentang nama nama siswa, yang menjadi sampel dalam penelitian, selain itu dokumentasi digunakan untuk memperoleh nilai awal siswa atau nilai rata - rata mata pelajaran PKN pada materi sebelumnya yang berguna untuk mengetahui tingkat kemampuan siswa. Dan adapaun data - data yang diperoleh oleh penulis yaitu daftar nama jumlah siswa kelas VIII dan foto dokumentasi penelitian.

4. Instrumen penelitian.

Instrumen penelitian adalah alat atau fasilitas yang digunakan oleh peneliti dalam mengumpulkan data agar pekerjaannya lebih mudah dan hasil lebih baik, dalam arti lebih cermat, lengkap, dan sistematis sehingga lebih mudah diolah (Arikunto, 2010). Tes hasil belajar yang digunakan adalah tes obyektifberupa pilihan ganda, tes ini dibuat untuk mengetahui kemampuan siswa dalam memahami materi yang telah diajarkan.Jumlah soal yang digunakan sebanyak 25 soal. Dari uraian diatas, instrument penelitian dalam penelitian ini berupa test obyektif untuk nilai post-test

1) Hasil uji validitas

Tabel 3

Table hasil uji validitas

\begin{tabular}{|c|c|c|}
\hline No & interval & keterangan \\
\hline 1 & $0,800-1,00$ & Sangat tinggi \\
2 & $0,600-0,800$ & Tinggi \\
3 & $0,400-0,600$ & Cukup \\
4 & $0,200-0,400$ & Rendah \\
5 & $0,00-0,200$ & Sangat rendah \\
\hline
\end{tabular}

\begin{tabular}{|c|c|c|l|}
\hline $\begin{array}{c}\text { Butir } \\
\text { soal }\end{array}$ & Rpbis & rtabel & Valid/invalid \\
\hline 1 & 0,266707 & 0,381 & Invalid \\
\hline 2 & 0,411129114 & 0,381 & Valid \\
\hline 3 & 0,429147215 & 0,381 & Valid \\
\hline 4 & 0,221973873 & 0,381 & Invalid \\
\hline 5 & 0,449594937 & 0,381 & Valid \\
\hline 6 & 0,265876177 & 0,381 & Invalid \\
\hline 7 & 0,428257437 & 0,381 & Valid \\
\hline 8 & 0,58279361 & 0,381 & Valid \\
\hline 9 & 0,427869873 & 0,381 & Valid \\
\hline 10 & 0,45094557 & 0,381 & Valid \\
\hline 11 & 0,326481013 & 0,381 & Valid \\
\hline 12 & 0,583282753 & 0,381 & Valid \\
\hline 13 & 0,344929367 & 0,381 & Valid \\
\hline 14 & 0,481177468 & 0,381 & Valid \\
\hline 15 & 0,490617038 & 0,381 & Valid \\
\hline 16 & 0,550053519 & 0,381 & Valid \\
\hline 17 & 0,450454648 & 0,381 & Valid \\
\hline 18 & 0,563968987 & 0,381 & Valid \\
\hline 19 & 0,470256281 & 0,381 & Valid \\
\hline
\end{tabular}

\begin{tabular}{|c|c|c|l|}
\hline 20 & 0,024807089 & 0,381 & Invalid \\
\hline 21 & 0,256287471 & 0,381 & Invalid \\
\hline 22 & 0,38120561 & 0,381 & Valid \\
\hline 23 & 0,449654684 & 0,381 & Valid \\
\hline 24 & 0,421682218 & 0,381 & Valid \\
\hline 25 & 0,410602506 & 0,381 & Valid \\
\hline
\end{tabular}

Dari penjelasan tabel di atas dapat dilihat bahwa instrumen yang valid yaitu 25 soal dan instrumen yang tidak valid yaitu 5. Hasil uji coba validitas instrumen yang terdiri dari 25 butir soal, dimana penguji dilakukan dengan membandingkan nilai $\mathrm{r}_{\text {hitung }}$ tiap butir soal dan $\mathrm{r}_{\text {tabel }}$. Nilai $\mathrm{r}_{\text {tabel }}$ yang digunakan adalah nilai $\mathrm{r}$ pada taraf signifikan $5 \%$ untuk $\mathrm{N}=27$ yaitu 0,381dengan kriteria diperoleh 20 butir soal yang valid dan 5 butir soal yang tidak valid. Setelah itu baru dibandingkan dengan harga korelasi yakni $\mathrm{R}_{\text {pbis. }}$

2) Hasil uji realibitas

$$
\begin{aligned}
& S^{2}=\frac{\sum x^{2} \frac{\left(\sum x\right)^{2}}{N}}{N} \\
& S^{2}=\frac{\sum 5797 \frac{(411)^{3}}{29}}{29}
\end{aligned}
$$

$\begin{gathered}\begin{array}{c}= \\ \sum 5797 \frac{(168921)}{29}\end{array} \\ 29\end{gathered}=\frac{5797-5824,8}{29}=\frac{-27,8}{29}=-0,958$

$$
\begin{aligned}
& \mathrm{R}_{11}=\left(\frac{n}{n-1}\right)\left(\frac{s^{2}-\sum p q}{s^{2}}\right) \\
& =\left(\frac{29}{28}\right)\left(\frac{-0,985-(77,257)}{-0,985}\right) \\
& =1,03\left(\frac{-78,242}{-0,985}\right) \\
& =1,03(79,43) \\
& =81,812
\end{aligned}
$$

\section{Metode Analisis Data}

a. Uji normalitas

Menurut sugiyono (2013:193) uji normalitas dilakukan untuk mengetahui apakah posttest berdistribusi normal atau tidak . Uji normalitas dicari dengan menggunakan rumus chi - kuadrat.

Keterangan :

$\mathrm{X}^{2}=$ chi - kuadrat

$F O=$ frekuensi yang diobservasi

$\mathrm{Fe}=$ frekuensi yang diharpkan

$\mathrm{K}=$ banyaknya kelas interval

Dimana fo menyatakan kelas frekuensi yang diharpkan berdasrkan disrtibusi frekuensi kurva normal. 
Data bersdistribusi normal jika nilai $\mathrm{x}^{2}$ hitung $<\mathrm{x}^{2}$ tabel pada taraf signifikan $5 \%$ dengan derajat kebebasan $\mathrm{db}=$ $\mathrm{k}-1$, dimana $\mathrm{k}$ adalah jumlah kelas interval.

b. Uji Homogenitas (Statistik F)

Data yang diperoleh terlebih dahulu dianalisis dengan uji Funtuk mengetahui kehomogenan varians.Menurut Sugiyono (2007) Pengujian homogenitas varians digunakan uji $\mathrm{F}$ dengan rumus :

$$
F=\frac{\text { variansterbesar }}{\text { variansterkecil }}
$$

\section{c. Uji Hipotesis}

Uji hipotesis bertujuan untuk mengetahui tingkat kemampuan siswa.Hasil yang diharapkan dari uji hipotesis ini adalah adanya kemampuan siswasesudah diberikan perlakuan.Analisis data yang digunakan dalam penelitian ini adalah $t$-test atau biasa disebut dengan ujit.Uji-t adalah tes statistik yang dapat dipakai untuk menguji perbedaan atau kesamaan dua kondisi/perlakuan atau dua kelompok berbeda dengan prinsip membandingkan rata-rata (mean) kedua kelompok/prilaku itu. Menurut Sugiyono (2007) Rumus yang digunakan adalah rumus $t$-test sebagai berikut:

$$
t_{\text {tes }}=\frac{\bar{X}_{1}-\bar{X}_{2}}{\sqrt{\frac{S_{1}{ }^{2}}{n_{1}}+\frac{S_{2}{ }^{2}}{n_{2}}}}
$$

$t$ = angka atau koefisien derajat perbedaan mean kedua kelompok

$\overline{\mathrm{X}}_{1}=$ rata-rata populasil 1

$\overline{\mathrm{X}}_{2}$ = rata-rata populasi 2

$\mathrm{S}_{1}{ }^{2}=$ nilai varian pada populasi 1

$\mathrm{S}_{2}{ }^{2}=$ nilai varian pada populasi 2

$\mathrm{n}_{1}=$ jumlah individu pada poplasi 1

$\mathrm{n}_{2}=$ jumlah individu pada populasi 2

\section{HASIL DAN PEMBAHASAN}

\section{Hasil Penelitian}

Untuk mendeskripsikan hasil penelitian ini, langkah pertama yang dilakukan adalah pengukuran hasil belajar anak dengan tidak menggunakan model pembelajaran student facilitator and explaining kemudian dikenakan perlakuan untuk jangka waktu tertentu dengan model pembelajaran student facilitator and explaining, dengan menggunakan tes untuk mendapatakan nilai hasil belajar siswa.

Dalam penelitian ini nilai yang akan dibahas adalah tentang hasil belajar siswa yang menggunakan model lain dan hasil belajar siswa yang menggunakan model SFAE dan data tersebut berbentuk kuantitatif, yaitu bersifat angka -angka sehigga untuk pemecahan masalah atau menganalisa adalah dengan berbentuk kuantitatif yaitu melalui nilai tes hasil belajar siswa.

Deskripsi Hasil belajar siswa kelas control

Dari pengamatan awal lokasi penelitian bahwa model pembelajaran yang diterapkan guru selama ini masih terbatas pada model -model pemeblajaran yang menjenuhan siswa dalam belajar yang berakibat pada penurunan minat dan motivasi belajar sehingga berakibat pada penurunan hasil belajar. Ini terlihat dalam pelajaran PPKn adalah rendahnya hasil belajar siswa dengan nilai rata - rata dibawah KKM.

Data dalam penelitian ini berupa data hasil belajar siswa. Data hasil belajar ditunjukan dengan nilai posttes. Sebelum pengambilan data untuk nilai posstes dalam penelitian ini terlebih dahulu dilakukan uji instrument untuk mengetahui kevalidan instrument dala penelitian ini, dilakukan dengan cara uji coba test pilihan ganda, maka dalam table dibawah ini, data yang telah dikumpulkan kan dideskiripsikan sesuai dengan data variable penelitian, yakni yang tidak menggunakan model pembelajaran SFAE terhadap hasil belajar siswa pada mata pelajaran PPKn kelas VIIIa di MTs Nurul Qur'an pagutan tahun pelajaran 2015/2016.

Dari data yang dikumpulkan melalui hasil belajar pada kelompok SFAE dengan jumlah 26 siswa, diamana nilai rata 70,23, simpangan baku 5,40, modus 70 dan median 70,1 dengan nilai tertinggi 80 dan nilai terendah 6o. Lihat di (lampiran 8).

Deskripsi Hasil belajar siswa kelas eksperiment

Setelah melakukan tes awal maka, peneliti mendapatkan hasil studi lapangan untuk pembelajaran yang berbeda antara kelompok kontrol dan kelompok eksperimen. Dari data yang dikumpulkan melalui hasil belajar pada kelompok SFAE dengan jumlah 29 siswa, dimana nilai rata 72,37,simpangan baku 8,04, modus 76 dan median 74,285 dengan nilai tertinggi 90 dan nilai terendah 6o. Lihat di (lampiran8).

Pengujian prasyarat analisis

Sebelum dilakukan pengujian hipotesis, maka terlebih dahulu dilakukan uji prasyarat analisis berupa uji homogenitas untuk mengetahui apakah varian kedua sampel homogeny atau tidak.

Tabel 4

Hasil belajar Siswa di kelas Kontrol dan Eksperimen

\begin{tabular}{|c|l|c|c|}
\hline \multirow{2}{*}{ No } & \multirow{2}{*}{ Deskripsi } & \multicolumn{2}{|c|}{ Nilai Hasil Belajar } \\
\cline { 3 - 4 } & $\begin{array}{c}\text { Eksperime } \\
\mathrm{n}\end{array}$ & Kontrol \\
\hline 1 & Nilai Minimum & 60 & 60 \\
\hline 2 & $\begin{array}{l}\text { Nilai } \\
\text { Maksimum }\end{array}$ & 90 & 80 \\
\hline 3 & $\begin{array}{l}\text { Rata-rata } \\
\text { (mean) }\end{array}$ & 70,72 & 70,23 \\
\hline 4 & Median & 74,312 & 70,1 \\
\hline 5 & Modus & 76,5 & 70 \\
\hline 6 & Standar Deviasi & 8,043 & 5,393 \\
\hline 7 & Varians & 64,7 & 29,094 \\
\hline \multicolumn{2}{|c|}{65} \\
\hline
\end{tabular}

Uji kepatutan yang digunakan untuk menganalisis data tes hasil pengaruh model pembelajaran SFAE siswa adalah uji perbedaan dua rata-rata. Uji perbedaan dua rata-rata yang akan digunakan adalah uji t.

\section{a. Uji Homogenitas}

Berdasarkan hasil perhitungan untuk uji homogenitas varians data dapat ditentukan dengan membandingkan harga Fhitung dan Ftabel.Jika Fhitung > Ftabel, maka disimpulkan bahwa varians data bersifat tidak homogeny. Sebaliknya jika Fhitung $\leqslant$ Ftabel, maka disimpulkan bahwa varians data homogeny. Setelah melakukan analisis berdasarkan perhitungan pada lampiran 9.

Untuk lebih jelasnya hasil dari uji homogenitas dapat dilihat pada tabel berikut:

Tabel 5

Rekapitulasi Hasil Perhitungan Uji Homogenitas 


\begin{tabular}{cccccc}
\hline Kelas & $\begin{array}{c}\text { Jumlah } \\
\text { sampel }\end{array}$ & $\begin{array}{c}\text { Varians } \\
\left(\mathbf{S}^{2}\right)\end{array}$ & $\begin{array}{c}\mathbf{F} \\
\text { hitung }\end{array}$ & $\begin{array}{c}\boldsymbol{X}^{2} \\
\text { tabel } \\
= \\
\mathbf{5 \%}\end{array}$ & $\mathbf{K}$ \\
\hline Eks & 29 & 64,7 & & & \\
Ktr & 26 & 29,094 & 2,223 & 1.92 & $\begin{array}{c}\text { Tidak } \\
\text { homogen }\end{array}$
\end{tabular}

Karena F hitung lebihdari $F$ tabel $(2,223>1,92)$ maka $\mathrm{H}_{\mathrm{a}}$ diterima, artinya kedua varians populasi tidak homogen.

\section{b. Uji normalitas}

Berdasarkan hasil posttest, peneliti melakukan uji normalitas data untuk mengeahui apakah data hasil belajar siswa, baik kelas eksperimen dan control tersebut berdistribusi normal atau tidak jika x2hitung < x2tabel pada taraf signifikan $5 \%$ dengan dk $=\mathrm{k}-1$.

Hasil perhitungan di peroleh x2hitung $=3,481$ dan x2tabel 4,35 pada taraf signifikan 5\%. Berdasrkan criteria pengujian jika x2hitung $\leq$ x2tabel, maka data tersebut terdistribusi normal. Dengan demikian hasil kelompok yang diajarkan dengan metode cermah, hasil perhitungan diperoleh x2hitung $=2,57$ dan x2tabel 4,35 pada taraf signifikan $5 \%$. Berdasarkan criteria pengujian jika x2hitung $\leq$ x2tabel, maka data tersebut terdistribusi normal

\section{c. Uji Hipotesis}

Kriteria pengujian: Jika thitung < ttabel, maka Ho diterima, Jika thitung >ttabel maka Ho ditolak dengan taraf signifikan 0,05 dan $\mathrm{dk}=53$. T-test dilakukan dengan menggunakan kelas eksperimen dan kelas Kontrol dengan nilai uji $\mathrm{t}=0,146$

Setelah thitung diperoleh, langkah selanjutnya yaitu menentukan ttabel dengan derajat kebebasan $(\mathrm{dk})=\mathrm{n} 1$ $+\mathrm{n} 2-2=29+26-2=53$, karena dalam ttabel tidak tercantum dk 53 dan di dalam ttabel dk tersebut berada antara $\mathrm{dk}=40 \mathrm{dan} \mathrm{dk}=60$, maka ttabel harus dicari dengan menggunakan rumus Interpolasi Linier sehingga diperoleh hasil dari perhitungan tersebut pada taraf signifikan 0,05 yaitu sebesar 2.02.

Kesimpulan: Karena didapat thitung $<$ ttabel $(0,246<$ 2,02) maka hipotesis nol (Ho) diterima dan hipotesis alternatif (Ha) ditolak, artinya tidak terdapat pengaruh yang signifikan antara hasil belajar PPKn yang diajarkan melalui model pembelajaran Student Facilitator and Explaining pada kelas eksperimen.

\section{Pembahasan}

Model pembelajaran kooperatif dan pembelajaran metode ceramah merupakan dua model pembelajaran yang tidak sama. Model pembelajaran kooperatif tidak dapat meningkatkan hasil belajar siswa

Dalam proses belajar mengajar ada beberapa unsur yang sangat penting diantaranya mengenai metode mengajar dan model pembelajaran. Penggunan metode dan model pembelajaran tepat diharapkan mampu membuat siswa berperan aktif sehingga berpengaruh terhadap hasil belajar siswa.Salah satunya dengan menggunakan model pembelajaran SFAE.

Pada dasarnya hasil belajar sangat dipengaruhi oleh beberapa factor, seperti factor internal maupun factor eksternal serta pendekatan pembelajaran. Factor internal adalah factor yang ada didalam diri individu yang sedang belajar, kemudian factor eksternal factor yang ada diluar individu, sedangkan pendekatan pembelajaran adalah bagaimana kualitas dan strategi pengajaran yang digunakan dalam proses belajar mengajar. Data hasil penelitian berupa nilai yang diperoleh dari hasil tes soal pada siswa Mts Nurul Qur'an Pagutan yang dilakukan pada kedua kelas yaitu kelas kontrol (VIIIA), kelas eksperimen (VIIIB) dan dimana kelas eksperimen diberi perlakuan dengan menerapkan model pembelajaran SFAE sedangkan pada kelas kontrol diberi perlakuan dengan metode diskusi informasi yaitu metode yang biasa digunakan oleh guru mata pelajaran di sekolah tersebut. Rata -rata hasil belajar siswa kelas eksperimen dan kelas kontrol.

Berdasarkan yang dilakukan uji normalitas untuk kelas eksperimen dan control, berdasarkan hasil perhitungan diperoleh bahwa data kedua kelas adalah berdistribusi normal. Dari hasil pengujian hipotesis diperoleh nilai thitung $=3,481$ sedangkan ttabel $=4,35$ pada taraf signifikan 5\%. Berdasarkan criteria pengujian thitung > ttabel maka Ho ditolak dan $\mathrm{Ha}$ diterima. Dengan demikian dapat dikatakan bahwa ada perbedaan model pembelajaran kooperatif tipe SFAE dan model pembelajaran konvensional.

Hasil tes siswa antara kelas ekspererimen dan kelas kontrol ternyata tidak memiliki perbedaan yang signifikan jika ditinjau dari rata- rata diatas. Hal ini terlihat jelas dari peningkatan hasil belajar di kelas eksperimen dengan rata-rata sebesar 70,72 dan hasil belajar pada kelas kontrol dengan rata-rata 70,23. Berhubungan dengan hal tersebut uji homogenitas data menunjukkan hasil data yang tidak homogen dimana, nilai Fhitung $>$ Ftabel $(2,223>1,92)$.

Sehingga pengaruh penggunaan metode SFAE dianalisis menggunakan t-test separated varians, Dengan perolehan (lampiran ) dengan hasil, thitung lebih kecil dari ttabel $(0,246<2,02)$, dengan demikian dapat dinyatakan bahwa tidak ada pengaruh yang signifikan pada hasil belajar siswa antara kelas eksperimen yang menggunakan model pembelajaran SFAE dengan kelas kontrol yang menggunakan metode diskusi informasi pada mata pelajaran PPKn.

Tidak adanya pengaruh dalam hasil belajar dikarenakan penggunaan model pembelajaran yang masih bersifat baru dan siswa masih belum beradaptasi dengan model pembelajaran tersebut. Disamping itu pula waktu penelitian yang dilakukan relatif singkat dalam kurun waktu sebulan. Selain itu, sintak pada model pembelajaran SFAE terdapat adanya kelemahankelemahan. Kelemahan model pembelajaran SFAE salah satunya membuat siswa lebih banyak bermain dalam kelompok masing-masing, kurangnya memperhatikan penjelasan teman dan siswa merasa gugup ketika menjelaskan materi pelajaran didepan kelas.

Dalam menyelesaikan tes evaluasi (posttest) siswa masih merasa ragu-ragu dan takut, setiap pertanyaan yang ada siswa menjawab dengan kurang hati-hati, sehingga dampaknya pada hasil belajar. Faktor lain yang menyebabkan kurang peningkatan pada hasil belajar siswa adalah tingkat pemahaman (inteligensi) dan daya serap setiap siswa berbeda-beda. Inteligensi besar pengaruhnya terhadap kemajuan hasil belajar.

Dalam situasi yang sama, siswa yang mempunyai tingkat inteligensi yang tinggi akan lebih berhasil 
daripada yang mempunyai tingkat inteligensi yang rendah. Selain faktor inteligensi, minat juga besar pengaruhnya terhadap hasil belajar, dimana bila materi yang dipelajari tidak sesuai dengan minat siswa, siswa tidak akan belajar dengan sebaik-baiknya, karena tidak ada daya tarik bagi siswa tersebut.

Dengan demikian model pembelajaran SFAE tidak ada pengaruh terhadap hasil belajar PPKn kelas VIII MTs Nurul Qur'an Pagutan.

\section{SIMPULAN DAN SARAN}

Hasil penelitian menunjukkan bahwa model pembelajaran SFAE tidak memiliki pengaruh terhadap hasil belajar PPKn siswa. Dari hasil pengujian hipotesis diperoleh nilai thitung $0,146<2,02$ ttabel pada taraf signifikan 5\%. Berdasarkan criteria pengujian thitung < tabel maka $\mathrm{H}_{\mathrm{O}}$ diterima dan Ha ditolak.

Oleh sebab itu, menyarankan bahwa model pembelajaran SFAE perlu diterapkan oleh guru dikarenakan model pembelajaran ini dapat menunjang kemampuan berkomunikasi dan hasil belajar, meskipun dalam penelitian ini tidak adanya pengaruh terhadap hasil belajar siswa akan tetapi keberhasilan proses pembelajaran juga dipengaruhi oleh tingkat inteligensi dan daya serap siswa itu sendiri. Kepada guru perlu menerapkan model pembelajaran SFAE pada mata pelajaran lain. Kepada mahasiswa yang ingin meneliti lebih lanjut diharapkan dapat mencoba dan menerapkan model pembelajaran SFAE pada pokok bahasan yang sama sehingga diharapkan dapat memperbaiki hasil penelitian ini.

\section{UCAPAN TERIMA KASIH}

Penulis mengucapkan terima kasih kepada editor yang senantiasa memberikan saran dan masukan kepada penulis sehingga artikel ilimiah ini selesai dengan baik.

\section{DAFTAR RUJUKAN}

[1] S. B. Djamarah, “Aswan zain. 2010,” Strateg. Belajar Mengajar.

[2] I. K. Ahmadi, Strategi Pembelajaran Sekolah Terpadu. Jakarta: RajaGrafindo Persada, 2013.

[3] K. Khaeruman, S. N. Nurhidayati, and S. Rahayu, "Efektifitas Penerapan Model Pembelajaran Problem Solving Dengan Context-Rich Problems Pada Materi Pokok Termokimia Dalam Meningkatkan Hasil Belajar Siswa Dan Kemampuan Berpikir Kritis," Prism. Sains J. Pengkaj. Ilmu dan Pembelajaran Mat. dan IPA IKIP Mataram, vol. 2, no. 1, pp. 18-26, 2014.

[4] P. D. Sugiyono, "Metode Penelitian dan Pengembangan," Res. Dev. D, 2015.

[5] W. Sanjaya, Perencanaan dan desain sistem pembelajaran. Kencana, 2015.

[6] A. Suharsimi, "Prosedur penelitian suatu pendekatan praktik,” Jakarta: Rineka Cipta, 2006.

[7] P. Sugiyono, Metode Penelitian Kuantitatif, Kualitatif, dan $R \& D .2013$.

[8] P. Sugiyono, “Dr. 2010," Metod. Penelit. Kuantitatif, Kualitatif, dan R\&D. Bandung CV Alf.

[9] A. Sugiyono, "Pengantar Statistik Pendidikan," Jakarta Graf. Persada, 2004.

[10] N. Sudjana, Belajar dan Faktor-faktor yang
Mempengaruhinya. 2010. 